\title{
Some Sidelights on Chaucer's Alice of Bath
}

\section{Gillam}

Chaucer does not make extensive use of personal names for his pilgrims in the Canterbury Tales. ${ }^{1}$ A mere handful of them are distinguished by a personal appellation, and this is not usually employed more than once. Of the women on the pilgrimage, only one is named in her introductory portrait in the General Prologue; the Prioress's name, madame Eglentyne 'Sweet Briar,' introduced near the beginning of Chaucer's description of her, epitomizes everything that ladylike personage aspires to be. Here, one feels, is a woman aptly named. Its very fitness tacitly invites pleasurable specula tion as to how such a name was acquired: could it have been bestowed at baptism or on taking the veil, or was it a self-conferred soubriquet, chosen in emulation of those courtly heroines of French romances upon whom, no doubt, the French taught at the convent of Stratford atte Bowe inspired this devoted student to model herself? ${ }^{2}$ The Prioress's chapeleyne, the Second Nun, a dim figure beside her charming superior, is neither characterized nor named in the General Prologue, although in her own Prologue she reveals a pedantic interest in the significance of names, citing various conjectural etymologies of her heroine's and pointing out their appropriateness to the personality and life of Saint Cecilia. ${ }^{3}$ Her concern with meaningful naming inevitably redirects attention to both the aptness of Eglentyne for an aspirant to cheere of court and its dubious suitability for one supposedly dedicated to religion.

Chaucer's choice of name for his third woman pilgrim, the Wife of Bath, is as important as the selection of Eglentyne for the Prioress, although its significance may not be equally apparent to the modern reader. Not surprisingly, the Wife, a character with an overdeveloped sense of individuality and identity, is allowed to reveal what she is called herself. She mentions her own name twice in the Prologue to her Tale, using both Alys (320) and its diminutive Alisoun (804). She also reveals that her close crony shares both forms of the name with her: Alisoun (530); Alys (548). The choice of name produces some interesting reverberations in the Wife's

Alice of Bath 
Prologue; her first reference to Alys occurs when she is recreating a wrangle with one of her old husbands, over her right to the goods in his cheste and to her own wayward freedom. In its immediate context alys rhymes with talys:

\author{
"Wyf, go wher thee liste; \\ Taak youre disport, I wol nat leve no talys. \\ I knowe yow for a trewe wyf, dame Alys."
}

(318-320)

This rhyming collocation sets up a covert association of ideas - that Alys and talys do indeed belong together, subtly contradicting the lesson the Wife is overtly attempting to inculcate, that Alys should by no means be linked with talys in her husband's mind. The underlying association is confirmed when the Wife reiterates the Alys/talys rhyme in speaking of her namesake gossib:-

And so bifel that ones in a Lente -

So often tymes I to my gossyb wente,

For evere yet I loved to be gay,

And for to walke in March, Averill, and May,

Fro hous to hous, to heere sondry talys -

That Jankyn clerk, and my gossyb dame Alys.

And I myself, into the feeldes wente.

The Alys/talys association obviously struck Skelton, who employed it together with a suggestive pun on the name and its possessor's drinking habits: Than thydder came dronken Ales/And she was full of tales ... Possibly the same association was at the back of Chaucer's mind when he named a woman who was also fond of her tipple. ${ }^{5}$

In the two contexts where the Wife uses the diminutive, Alisoun, a more intimate relationship between the user of the pet name and its possessor is indicated than in the contexts where Alys is employed; she recalls vividly the absolute confidence she reposed in her gossib:

My fifthe housbonde, God his soule blesse!

Which that I took for love, and no richesse,

He som tyme was a clerk of Oxenford,

And hadde left scole, and wente at hom to bord

With my gossib, dwellynge in oure toun;

God have hir soule! hir name was Alisoun.

She knew myn herte, and eek my privetee,

Bet than oure parisshe preest, so moot I thee!

Alice of Bath 
To hire biwreyed I my conseil al ...

and also an emotional peak in her married life with Jankyn:

And neer he came, and kneled faire adoun,

And seyde, "Deere suster Alisoun,

As help me God! I shal thee nevere smyte.

That I have doon, it is thyself to wyte.

Foryeve it me, and that I thee biseke!"

(803-807)

In these instances, where Alisoun replaces Alys, there are slightly ominous undertones to the rhyming words: toun and adoun; the first is faintly suggestive of 'women of the town,' the second of an encounter anything but elevating; but the chief purpose of the pet name is to signal a close relationship between its bearer and the person using it. Whereas in the Alys contexts the relationship is affected by third party considerations: the talys of scandalmongers in the case of the young wife and old husband, the presence of Jankyn, the subject of temporarily suppressed confidences, in the case of the two Alices, in the Alisoun contexts it is of primary importance. In the earlier passage, Chaucer reinforces the bonds of intimacy and shared interests between Alisoun of Bath and her gossib by giving them not only the same name but the same pet name. ${ }^{6}$ The tie between the two women is strengthened by their common interest in Jankyn. The accommodating part played by the second Alisoun during the Wife's pursuit of her beloved young cleric creates in the Wife an unaccustomed charity towards another woman, a charity noticeably absent from other spheres of her life, judging from her feelings towards any woman foolhardy enough to make her offrynge before her. ${ }^{7}$ Gossip Alisoun is the Wife's alter ego, foremost among those to whom the most intimate details of a husband's physical and moral life are related:

For hadde myn housebonde pissed on a wal,

Or doon a thyng that sholde han cost his lyf,

To hire, and to another worthy wyf,

And to my nece, which that I loved weel,

I wolde han toold his conseil every deel.

(534-538)

In the second Alisoun passage, the Wife puts the pet version of her name into Jankyn's mouth as she quotes his plea for reconciliation with her during their last quarrel. The switch from dame Alys, which she had put 
into the mouth of her despised elderly husband, to Alisoun from the lips of Jankyn is a tribute both to her greater affection towards the younger man and to his ability to glose and wynne agayn [hir] love anon. There is also a wistful nuance of momentary regeneration for the widow as she relives a touching scene in which an Alisoun with a clerical husband recalls the stock situation of the girl with a clerical lover. The moment is rich in irony as the reader sees, through the Wife's eyes, a fleeting vision of an Alisoun resembling the heroine of The Miller's Tale with her hende Nicholas in a middle-aged woman's remembrance of her relationship with a man half her age. ${ }^{9}$

There may well be a covert pun on Alisoun/eleison in both passages where the diminutive is preferred to Alys. ${ }^{10}$ In the first passage, the Wife declares that her gossib knew her privetee better than their Parish Priest, which suggests that the easy-going recipient of her confidences stood in the relationship of a confessor to her and that unburdening herself to another Alisoun afforded some of the relief or mercy available from shrift. Since, in the second passage, Clerk Jankyn is begging on his knees for forgiveness from his Alisoun for striking her, the same pun, rich in courtly (pitee renneth soone in gentil herte) ${ }^{11}$ as well as ecclesiastical connotations is probably in play here too, as a lover craves mercy from a tyrannical lady and yet another of Adam's mark (and a cleric at that!) falls a victim to Eve's maistrie.

There is abundant evidence that Alice was a highly popular name in mediaeval England. ${ }^{12}$ It was certainly favored near Bath; Professor Manly, basing his information on Ancient Deeds, a publication of the Bath Records Society, writes:-

... Alice (or Alysoun) seems the commonest name among the women who figure in these documents, and curiously enough more than one of these Alices rejoiced in three or more husbands, though I can find none who had clearly achieved five. ${ }^{13}$

The Oxford Dictionary of English Christian Names ascribes the popularity of Alice to the influence of la bele Aelis, the heroine of early French dance-songs. ${ }^{14}$ Although at first glance this French Aelis and her Chaucerian namesake bear little resemblance to each other, a closer look reveals that they have something in common after all. ${ }^{15}$ The very name bele Aelis became synonymous with the dance itself and all that the church found to disapprove of in dancing. ${ }^{16}$ Not only does Chaucer's Wife pride herself on her dancing (How koude I daunce to an harpe smale), ${ }^{17}$ but Chaucer brings his introductory portrait of her, in the General Prologue, to a climax with a commendation of her intimate 
knowledge of that olde daunce (476) that censorious clerics had seen epitomized in the actual dancing of la bele Aelis. Both ladies are the chief protagonists in women-centered dramas which they act out for the benefit of an audience, Aelis in mime, Alys in first person narration to her pilgrim audience. Both initiate the amorous adventures of the olde daunce; Aelis calls men to dance with her; ${ }^{18}$ Alys of Bath glories in her own contrivance and foresight in planning her love affairs; she too can be said to call men into the dance with her. Both characters provide a target for misogynistic attack and become the subject of anti-feminist satire, Aelis no less than Alys; one sermonizer wrote of her:

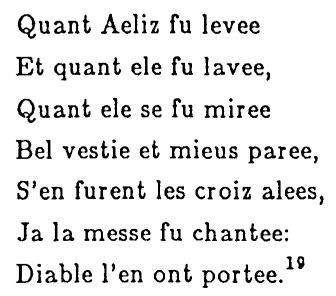

The fear behind such condemnations goes far deeper than mere distrust of feminine frivolity. Dancing itself and especially dancing women evoked the fearful spectre of resurgent paganism in women-led rites and womencentered festivals that had evaded the restrictions of patriarchal orthodoxy across the centuries. ${ }^{20}$ Aelis and Alys were both symbols of an irrepressible female principle that roused alarm and despondency in mediaeval male breasts.

Chaucer would undoubtedly have been aware of all that la bele Aelis and his Wife of Bath had in common; he may also have known of the matrimonial antics of some of those other Alices of Bath cited by Professor Manly ${ }^{21}$ but it is also possible that he was partially influenced in his choice of name for a headstrong and grasping woman by the notorious reputation of Alice Perrers, mistress of Edward III. ${ }^{22}$ Although at the height of her notoriety earlier in the century, this historical Dame Alice did not die until 1400 and, after her royal lover's death, was still in the public eye from time to time, fighting to save her reputation and property from her detractors. Genuine evidence of an acquisitiveness more than equal to that of the Wife of Bath seems plentiful enough, while rumour has endowed her with a cupidity that led her to snatch the rings from Edward's fingers on his deathbed. ${ }^{23}$ One account credits this Alice with West Country origins (albeit from beside Exeter, not Bath), and with being the daughter of a weaver, ${ }^{24}$ although no one seems to have suggested that she herself excelled in that art. There is official confirmation

\section{Gillam}


that she was sometimes referred to by the diminutive of her name, as were both Alison of Bath and her gossip. ${ }^{25}$ Like the Wife, Alice Perrers knew all about aging lovers, ${ }^{26}$ and, when no longer young herself, she apparently maintained a tame cleric. ${ }^{27}$ Whether or not she was married more than once is uncertain, but she was certainly married to a William, Sir William Windsor, ${ }^{28}$ and the wife of Bath refers derisively to an old husband as Wilkyn (432). ${ }^{29}$

In her own way too, this Alice flouted male supremacy as successfully as Alice of Bath, for her activities on the bench at Westminster had resulted in the passing of an ordinance forbidding women to practice in the courts of law. ${ }^{30}$ It was in her nature, no less than in Chaucer's fictive Alice's, to challenge head-on a society that tried to constrain her and to struggle unremittingly to maintain her position and her rights. ${ }^{31}$ Both Alices attracted clerical disapproval: Alice Perrers from a hostile Chronicler, ${ }^{32}$ Alice of Bath from a misogynistic clerical husband. ${ }^{33}$ There is also a more conventional womanly resemblance between the historical and fictive Alices: both display fine clothes at public entertainments. In March, Averill, and May the wife went roving in her gaye scarlet gytes

To vigilies and to processiouns,

To prechyng eek, and to thise pilgrimages,

To pleyes of myracles, and to mariages

It is on record that in May 1376 special robes were appointed for Alice Perrers to appear at a hastilude ${ }^{34}$ and the Chronicle of London records an episode in the previous year that suggests splendid costuming and public display:

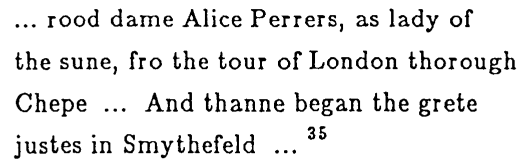

In Alice Perrer's procession there was alwey a lady ledynge a lordys brydell, ${ }^{36}$ a detail suggesting a connection with revels in which normal procedure was reversed and women held the maistrie, ${ }^{37}$ and casting an interesting sidelight too on a contemporary reality behind the Wife's metaphorical claim concerning the state of her matrimonial relationship with Jankyn: He yaf me al the bridel in myn hond. ${ }^{38}$

All this is not to suggest that Chaucer modelled his fictive Alice of Bath on the historical Alice Perrers any more than on those Alices of Bath discovered by Professor Manly, but that he may well have enjoyed 
weaving a strand or two drawn from current gossip into his complex portrait of her, knowing that links could and probably would be made. If he did so, he could be confident that the great popularity of the name shared by both ladies, and its wealth of literary associations, would enable him to claim or disclaim connections at will.

\section{The University of Wollongong}

\section{Notes}

${ }^{1}$ F.N. Robinson, ed., The Works of Geoffrey Chaucer, 2nd ed. (Cambridge, MA: The Riverside Press, 1957). Fragment I, line 121. All citations of Chaucer's work in this article refer to this edition. Italics used in quotations are mine.

${ }^{2}$ See Muriel Bowden, A Commentary on the General Prologue to the Canterbury Tales (London: Souvenir Press, 1973), 94.

${ }^{3}$ Robinson, VIII, $85 \mathrm{ff}$.

${ }^{4}$ R.S. Kinsman, ed., John Skelton: Poems (Oxford, 1969), 62.

5 Robinson, III, $459 \mathrm{ff}$.

- The gemination of names in mediaeval literature is a well-known phenomenon. E.g. in the romance Athelston the King and his messenger share the same name. This seems to suggest some special relationship or correspondence between the two; the King had originally been a messenger himself and is first introduced by the poet in that capacity. See A.V.C. Schmidt and N. Jacobs Medieval English Romances (London, 1980) pt. I, 124, 129, and 190 note 16.2.

${ }^{7}$ Robinson, I, $449 \mathrm{ff}$.

${ }^{8}$ Robinson, III, 509, 512.

'Dame Alys sounds a great deal more sedate than the diminutive and suggests a somewhat older woman. It is also the name of the Third Shepherd's mother, a lady whose name, incidentally, pops up in a tippling context, in the Wakefield Prime Pastorum; see A.C. Cawley, ed., The Wakefield Pageants in the Towneley Cycle (Manchester, 1958), 36, line 260. Alysoun, on the other hand, is the name of the very delectable heroine of one of the Harley Lyrics, and that it was associated with a sexually desirable (and perhaps available?) woman is suggested in its use by Usurpyd Power in Bale's Kynge Johan: Sumtyme I must hunt, sumtyne I must Alyson kys; see J.M. Manly, ed., Specimens of the Pre-Shakespearean Drama (New York: Dover Publications, repr. 1967), vol. I, 554, line 841. My colleague, Mr. R. McConchie, has drawn my attention to a later Alison of a similar type, called 'Alison Tripand-go,' in Jack Juggler. See Dodsley's Old English Plays, ed. W.C. Hazlitt, (London, 1874), vol. II, 117.

${ }^{10}$ I.e. from Kyrie eleison 'Lord have mercy.' One fifteenth-century poet was to develop the same pun into a full scale conceit in a dance song:

\section{Gillam}




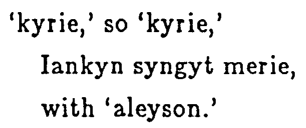

As I went on zol day in owr prosessyon

Knew I Ioly Iankyn be his mery ton.

[Kyrieleyson.]

See Secular Lyrics of the XIVth and XVth Centuries, ed. R.H. Robbins, 2nd ed. (Oxford: At the Clarendon Press, 1955), 21.

11 See Robinson 675, note on The Knight's Tale, line 1761, for instances of this line in Chaucer's works.

12 See A.D. Mills, "The Christian Names of Women in Fourteenth Century Dorset," Dorset Natural History and Archaeological Society Proceedings, vol. 88 (1966), 206. See too T.F. Mustanoja, "The Suggestive Use of Christian Names in Middle English Poetry," in Medieval Literature and Folklore Studies: Essays in Honor of Francis Lee Utley, ed. J. Mandel and B. A. Rosenberg (New Brunswick, 1970), 56, where Aalis is listed among the ten commonest names for women in thirteenth-century Paris.

13 J.M. Manly, Some New Light on Chaucer (London: G. Bell and Sons, Ltd., 1936), 234.

14 See E.G. Withycombe, The Oxford Dictionary of English Christian Names, 3rd ed. (Oxford, 1977), 15-16, for entries under Alice (from Germanic Adalhaidis) and Alison. See also Mustanoja, 70-71.

${ }^{15}$ On Bele Aelis sce J. Bedier, "Les Plus Anciennes Danses Francaises," Nouvelle Revue des Deux Mondes, vol. 31 (1906), 412-19. Mills, 205, considers the choice of Alys "a conscious irony" on Chaucer's part. It is undoubtedly so, but the most effective irony works both ways.

${ }^{10}$ See Bedier, 414.

${ }^{17}$ Robinson, III, 457.

${ }^{18}$ Bedier, 414.

${ }^{10}$ Bedier, 413.

${ }^{20}$ See E.K. Chambers, The Mediaeval Stage (1903; repr. London: Lowe and Brydone, 1963), vol. I, 161.

${ }^{21}$ See note 13 above.

${ }^{22}$ See The Dictionary of National Biography, ed. Sir Leslie Stephen and Sir Sidney Lee (founded 1882; publ. since 1917, London, O.U.P.) 898-900. I am greatly indebted to this article and to the authorities cited there for information concerning Alice's life and activities. For evidence that Chaucer and his family were likely to have been acquainted with Alice Perrers, see M.M. Crow and C.C. Olson, Chaucer Life Records (Oxford: Clarendon Press, 1966), 5, 89, 115-16, 295n. Haldeen Braddy, "Chaucer and Dame Alice Perrers," Speculum, xxi (1946), 222-28, argues for a closer familiarity, and in Chaucer's Parlement of Foules in its Relation to Contemporary Events (New York: Octagon Books, 1969), x, suggests 
a possible connection between the royal favorite and Chaucer's Alice of Bath without, however, giving any reasons for this or detailing any similarities. J. Gardner, The Life and Times of Chaucer (London: Jonathan Cape, 1977), 178ff. and 189 particularly, is more explicit, but the resemblances he discerns differ from those suggested in this article.

${ }^{23}$ See, for example, "Transcript of a Chronicle ... entitled, 'An Historicall Relation of certain passages about the end of King Edward the Third, and of his Death' ... " in Archaeologia, vol. 22 (1828), 281. The writer of the article on Alice Perrers in the DNB appears (899) to accept the story.

${ }^{24}$ See Archaeologia, vol. 22, 233, and Sir George Floyd Duckett, Duchetiana (London: Smith, 1874), 300 and the last (unnumbered) footnote on that page.

${ }^{25}$ See R.E.G. Kirk, ed., Life Records of Chaucer, (Ch. Soc., Sec. Ser., 1900), No. 58, 172, Aliceon Perrers.

${ }^{20}$ See Duckett, 299. P. Morant, The History and Antiquities of the County of Essex (London, 1763-1768), vol. I, 107, sees her as 'Abishag' to the King.

${ }^{27}$ See Calendar of Close Rolls (London: Kraus Reprint, 1972), Richard II, vol. I, 160, 706. (The entry reads ambiguously but it seems reasonable to assume that the chaplain mentioned here was Alice's and fell into misfortune with her rather than a member of the household of Reymunda de Bourke, to whom Richard II gave Alice's house in the parish of Allhallows. There is even a slender possibility that she was once involved with a 'Jankyn'): Item quod Jankyn ap Gwillim fornicatur cum Alicia Parrer, quoted by Rev. Canon A.T. Bannister, "Visitation Returns of the Diocese of Her eford in 1397," The English Hist. Rev, XLIV (1929), 445. There is no means of knowing the age of the said Jankyn but, if the Alice named here was the sometime royal favorite, she was nearing the end of her life (d. 1400). Did she, perhaps, like Alice of Bath, experience a tendresse for a younger man?

${ }^{28}$ For doubts over Alice's marital status and adventures, see the article in DNB cited in note 22 above, and also Notes and Queries, Ser. 7, VIII, 30-31. On her marriage to Sir William de Wyndesore, see T.R. Gambier-Parry, "Alice Perrers and Her Husband's Relatives," The English Hist. Rev., vol. 47 (1932), 273, and Close Rolls Richard II, vol. I, 457.

${ }^{29}$ The wife's use of the name is probably ironic. See Mustanoja, 53-54 and 66.

${ }^{30}$ See H.T. Riley, ed., Gesta Abbatum Monasterii Sancti Albani ... (London: Longmans, Green and Co., 1869), 230ff., and $D N B, 898-99$, with authorities cited there.

${ }^{31} \mathrm{DNB}$, passim.

${ }^{32}$ See Riley. 199-209.

${ }^{33}$ Robinson, III, 641ff. The weighty tradition of clerical disapproval behind this censure is demonstrated by R.A. Pratt, "Jankyn's Book of Wikked Wyves ... ," Annuale Mediaevale, vol. 3 (1962), 5-27.

${ }^{34} D N B$, 898. See also Chambers, 392. As Clerk of the King's Works, Chaucer was sometimes involved in erecting scaffolds at Smithfield for royal viewing on such occasions. See Life-Records of Chaucer, 287; here, too, the season is May.

${ }^{35}$ Sir Nicholas Harris Nicolas, Chronicle of London (London: 1827), 70. Skeat saw a resemblance between Langland's Lady Meed and Alice Perrers in their love of finery; see The

\section{Gillam}


Vision of William Concerning Piers the Plowman, ed. W.W. Skeat (1866; repr. London: O.U.P., 1954) vol. II, 31; Kittredge, The Date of Chaucer's Troilus and Other Chaucer Matters (London, 1905/1909), 79-80, cites Macauley's detection of a reference to Alice Perrers in Gower's Mirour, lines 22801-24.

30 Nicolas, 70.

${ }^{37}$ See E.K. Chambers, vol. I, $155 \mathrm{ff}$.

${ }^{38}$ Robinson, III, 813.

Names and Games: Onomastics and Recreational Linguistics (University Press, 1986) is an anthology of ninety-nine articles on names published in Word Ways between 1968 and 1986. Topics range from anagrams of Ronald Wilson Reagan (Insane Anglo Warlord) to rhyming and punning names of beauty parlors (We Curl Up And Dye) to surnames constiting of a single letter ( $O$, a Korean name, is the most common). By special arrangement withhte author, paperback copies can be ordered for $\$ 12.95$ postpaid from A. Ross Eckler, Spring Valley Road, Morristown NJ 07960.

Word Ways, The Journal of Recreational Linguistics, is published in four 64 -page issues per year for $\$ 15$, and is available from the above address. 